\title{
STABILIZED ERRORS: ATTRIBUTED PROBLEM IN TIMED AND NON-TIMED ARGUMENTATIVE WRITING
}

\author{
Rohmani Nur Indah
}

\author{
indah@bsi.uin-malang.ac.id \\ Fakultas Humaniora Maulana Malik Ibrahim State Islamic University \\ Alamat Korespondensi: Jl. Gajayana 50 Dinoyo Malang 65144
}

\begin{abstract}
This study is a case study seeking the relation between the errors students made in timed and non-timed argumentative writing. The use of good English language influences whether or not the students can develop their claim. The finding shows that students have fifteen types of stabilized errors, the dominant of which are verb tense, word choice and spelling. On language form, the stabilized errors mostly occur are omission and addition. Some students also show stabilized errors with reference to the negative transfer of their first language. In addition, the type of writing task results in different number of stabilized errors. Despite the favor on non-timed writing, some students show more careful language use without using the computer's spelling and grammar check. However, the type of writing task does not affect the number of errors as there is no significant difference between the two writing tasks. It supports the fact that post systematic errors are caused by several factors such as language transfer, intralingual interference and sociolinguistic situation. Accordingly, process approach writing is needed in which learners are given chance to make progress and, as suggested by Krashen's theory, to become optimal Monitor users.
\end{abstract}

Keywords: Stabilized Error, Argumentative Writing

\section{INTRODUCTION}

A child becomes an adult when he realizes that he has a right not only to be right but also to be wrong.

Thomas Szasz. The Second Sin, "Childhood".

To be wrong or to make mistake is inseparable from language learning process. When the mistake is repeated unconsciously, it becomes error. In applied linguistics, Error Analysis (EA) is "the study of patterns of errors"which is interesting to highlight as the focus of this study. Analysts have proposed several kinds of error. By discovering the type and pattern of occuring errors, it is expected that the root of the errors is also uncovered.

Established in the 1960s by Stephen Corder, EA was an alternative to contrastive analysis through which applied linguists sought to use the formal distinctions between the learners' L1 and L2 to predict errors. A key finding of $\mathrm{EA}$ has been that learners make faulty inferences about the rules of L2 (Elliot \& Lado, 2007). It might worsen the development of ideas in writing which in turn results in difficulties for its readers to understand the content.

Discussing EA is not merely emphasizing on correctness because linguistically speaking, correctness is not a valid concept (Cook, 2003, p. 6). Even in English, correctness resulted in hypercorrection i.e. changing pronoun John and me into John and I at any timebecause of the influence of Latin (Andersson \& Trudgill, 1990 , p. 109). Therefore, in this study the learner's errors are not viewed from how to correct them immediately but to explore how the learners view their own errors. 
Recent studies on error analysis mostly concern with those on timed writing essays or non-timed essay as separate matters. While, other studies concern with the comparison or the contrast between the two types of writing tasks, this study does not view the two types of writing tasks in terms of their difference. It relates between the errors in both timed and non-timed writing to see any stabilized errors found.

In this study, the term 'stabilized' is preferable to 'fossilized'. Fossilization means that the learner makes no further progress (Mason, 2002). Though stabilization is the first sign of presumed fossilization, stabilized errors are not permanent as fossilization. They are maintained in the learners' L2 production at a given level or it is just a momentary halt. In fact, learning is a process and learners are given chances to make progress (Long in Brown, 2007). Thus, the term stabilization, rather than fossilization, is favorable in this study because the subjects (English Department students) are still in the process of learning the TL.

This study is very significant as it gives clear pictures of the common phenomenon naturally occur in foreign language (FL) learning or second language acquisitions (SLA). English students, practitioners, and researchers will find useful implication for language teaching and learning. This also gives contribution to the applied linguistic field, in particular, to the debatable issue of error fossilization in SLA.

\section{Writing and Argumentation}

Writing as a process is seen as a recursive rather than linear, meaning that it includes prewriting, drafting and revising activities. During the process, fluency is considered more important than accuracy by helping learners understand well their own composing process (Brown, 2001). In the context of academic writing, this process requires learners critical thinking in treating the information related to the issue to be developed into an essay. Learners need to stimulate the recall of information for the purpose of reproducing knowledge (Crasswell, 2005). Such a process is needed to formulate a solid and well-developed argument.
Writing leads to learner's skill to identify a purpose, to produce and shape ideas and refine expression as well (White, 1995). This means that learners are generating ideas by using problem-solving process employing a range of cognitive and linguistic skills to produce a good argument. Accordingly, the teaching of reading and writing critically is significant especially for tertiary students. It aims at developing skills of critical thinking as well as critical reading and argumentative writing practices.

Argumentative writing is inseparable from reading critically. In order to write a good analysis and evaluation on a topic, careful critical reading of sources is essential to strengthen the argument. The judgments and interpretations made based on the texts are the first steps towards formulating the writer's own approach (Knott, 2009). By reading critically, learners can develop reflective skill before they actually start to write critically.

Therefore, it can be stated that critical thinking plays an important role in the development of argumentative writing skill. In addition such a development is also affected by the ability to read critically. This process generates the dynamic of critical thinking and both reading and writing critically. Indeed, this process is not always followed by the consistency of rethorical skill meaning that there might occur stabilized errors in learner's writing. This is due to the fact that wrting in second or foreign language requires not only the idea development but also correct and appropriate language use. This issue has become the starting point of this study.

\section{METHOD}

This study was conducted in the English department of UIN Maulana Malik Ibrahim Malang. It employs a case study as the object is the real writing process through text analysis to understand the actual experience faced by learners in developing their claim using correct language use. Data in this study are obtained from the main source namely document analysis on the essay writing and questionnaire on the learners' perspective on their writing errors.

The subjects of this study were 34 second-year students taking Writing 3 course. This study was initiated by assigning the 
research subjects to write an essay on the topic 'about writing'. This take-home assignment belongs to non-timed writing task. Then, in another meeting the research subjects take an essay quiz. As timed writing task, the instruction is to write an essay on the same topic in 90 minutes. The errors in both writing tasks are analyzed to find what the stabilized errors in the learners' timed and non-timed writing are and how the learners view their errors.

\section{FINDING AND DISCUSSION}

The Stabilized Errors in the Learners' Argumentative Writing

Based on the analysis on the 34 essays as the data of this study, the stabilized errors are summarized in table 1.

Table 1: Types of errors which are stabilized

\begin{tabular}{|c|c|c|c|c|c|c|c|c|c|c|c|c|c|c|c|c|c|}
\hline \multirow[t]{2}{*}{ SN } & \multicolumn{15}{|c|}{ Types of remained error in essay $1 \& 2$} & \multirow{2}{*}{$\begin{array}{l}\sum_{1} \text { er. } \\
\end{array}$} & \multirow[t]{2}{*}{$\sum$ er. 2} \\
\hline & $\mathrm{V}$ & $\mathrm{W}$ & $\mathrm{Sp}$ & $\mathrm{F}$ & Pc & $\mathrm{Pp}$ & Wo & A & $\mathrm{C}$ & $\mathrm{Cj}$ & M & $\mathrm{U}$ & $\mathrm{P}$ & $\mathrm{Pn}$ & $\mathrm{Ar}$ & & \\
\hline 1. & - & - & - & - & - & - & - & - & - & - & - & - & - & - & - & 0 & 3 \\
\hline 2. & $\sqrt{ }$ & - & - & - & - & - & - & - & - & - & - & - & - & - & - & 3 & 4 \\
\hline 3. & $\sqrt{ }$ & - & $\sqrt{ }$ & - & - & - & - & - & - & - & - & - & - & - & - & 9 & 2 \\
\hline 4. & $\sqrt{ }$ & - & - & - & - & - & - & - & - & - & - & - & - & - & - & 3 & 9 \\
\hline 5. & - & - & $\sqrt{ }$ & - & - & - & - & - & - & - & - & $\sqrt{ }$ & - & - & - & 9 & 8 \\
\hline 6. & $\sqrt{ }$ & - & - & - & - & - & - & $\sqrt{ }$ & - & - & - & - & - & - & - & 3 & 13 \\
\hline 7. & $\sqrt{ }$ & $\sqrt{ }$ & - & - & - & - & - & - & - & - & - & $\sqrt{ }$ & - & - & - & 10 & 9 \\
\hline 8. & - & $\sqrt{ }$ & - & - & - & - & $\sqrt{ }$ & $\sqrt{ }$ & - & - & - & - & - & - & - & 7 & 12 \\
\hline 9. & $\sqrt{ }$ & - & - & - & - & $\sqrt{ }$ & - & - & - & - & - & - & - & - & - & 13 & 8 \\
\hline 10. & $\sqrt{ }$ & $\sqrt{ }$ & $\sqrt{ }$ & - & - & - & - & - & - & - & - & - & - & - & - & 10 & 12 \\
\hline 11. & $\sqrt{ }$ & $\sqrt{ }$ & $\sqrt{ }$ & - & - & - & $\sqrt{ }$ & - & - & - & - & - & - & - & - & 10 & 16 \\
\hline 12. & - & $\sqrt{ }$ & - & - & $\sqrt{ }$ & $\sqrt{ }$ & - & - & - & - & - & $\sqrt{ }$ & - & $\sqrt{ }$ & - & 9 & 17 \\
\hline 13. & $\sqrt{ }$ & $\sqrt{ }$ & - & - & - & - & $\sqrt{ }$ & - & - & - & $\sqrt{ }$ & - & $\sqrt{ }$ & $\sqrt{ }$ & - & 19 & 10 \\
\hline 14. & $\sqrt{ }$ & $\sqrt{ }$ & - & $\sqrt{ }$ & - & - & - & - & - & - & - & - & - & - & - & 13 & 18 \\
\hline 15. & $\sqrt{ }$ & $\sqrt{ }$ & - & - & - & - & - & $\sqrt{ }$ & - & - & $\sqrt{ }$ & - & - & - & - & 10 & 26 \\
\hline 16. & $\sqrt{ }$ & $\sqrt{ }$ & $\sqrt{ }$ & - & - & - & - & - & - & - & - & - & - & - & - & 25 & 19 \\
\hline 17. & $\sqrt{ }$ & - & $\sqrt{ }$ & - & - & - & - & - & $\sqrt{ }$ & - & - & - & - & - & - & 9 & 45 \\
\hline
\end{tabular}

Note:

SN : subject number

$\mathrm{V}$ : verb tense

W : word choice

Sp : : spelling

Fr : fragment

Pc : punctuation

Pp : : preposition

Wo : word order

The type of errors above are adapted from the categorization proposed by Oshima \& Hogue (1999). As seen in table 1, the types of error which are stabilized cover verb tense $(76 \%)$ and word choice (53\%) as the dominant ones. Some students show that they cannot avoid the errors on spelling (35\%). The errors on word order, awkwardness, and unnecessary word (18\%) also occur. In addition, a few number of errors occur in wrong preposition and pronoun, and missing
A: awkwardness

C: capitalization

$\mathrm{Cj} \quad$ : conjunction

M : missing word

$\mathrm{U}$ : unnecessary word

P: plural

Pn : pronoun

$\mathrm{Ar} \quad$ : article

word (12\%). While, the least number of error is on fragment, punctuation, capitalization, plural marker (6\%).

There are errors occurring in separate essays, i.e. coordinate conjunction and wrong article meaning that they do not belong to stabilized errors. On the errors of article, students ignore the importance of it to point out objects and to bring someone to the attention. Although English article system is difficult for learners from many language backgrounds (Hatch \& Brown, 1995, p. 248), 
any Indonesian learner of English should not have great difficulty with it. This is because both languages (Indonesian and English) are conceptually similar in the use of article. Therefore, it does not belong to stabilized error.
In addition to the errors identified above, the stabilized errors also deal with the language form as categorized by Krashen et al. (1982) as follow:

Table 2: Samples of error in language form

\begin{tabular}{|c|c|c|c|}
\hline No & Type of Error & Examples & $\sum$ error \\
\hline 1. & Omission & $\begin{array}{l}\text { Deni } d o \text { the test (does/did) } \\
\text { The lecture gives the scores (lecturer) }\end{array}$ & 31 \\
\hline \multirow[t]{4}{*}{2.} & Addition & & 16 \\
\hline & a. Simple addition & $\begin{array}{l}\text { Our writing will be have meaning. } \\
\text { Does the each sentence give meaning? }\end{array}$ & 8 \\
\hline & b. Double marking & $\begin{array}{l}\text { They were dislike it (disliked) } \\
\text { I was really hate it (hated) }\end{array}$ & 3 \\
\hline & c. Regularization & $\begin{array}{l}\text { People may imaginate it (imagine) } \\
\text { They prefer to read than write (prefer reading } \\
\text { to writing) }\end{array}$ & 5 \\
\hline 3. & Double function & $\begin{array}{l}\text { It would be the problems of theirs (their } \\
\text { problem) } \\
\text { They prefer it to express theirselves } \\
\text { (themselves) }\end{array}$ & 3 \\
\hline 4. & Alternation & $\begin{array}{l}\text { Before writing, one will think what we will } \\
\text { write (he) }\end{array}$ & 1 \\
\hline 5. & Misordering & $\begin{array}{l}\text { Writing not only needs theory but also practice } \\
\text { (needs not only) } \\
\text { Let's see how can work it (it can work) }\end{array}$ & 4 \\
\hline & & & 55 \\
\hline
\end{tabular}

Based on table 2, omission (56\%) is mostly found which is followed by addition (29\%). The errors on omission occur mostly in the use of inflectional morphemes. According to Hatch and Brown (1995, p. 265), inflectional morphemes indicate the syntactic relation between words and function as grammatical markers. For instance the third person singular present tense morpheme applies to all verbs and plays a syntactic role in terms of verb agreement. In addition, inflectional morpheme errors are are more likely than derivational ones. This is apparently in line with the most stabilized errors found, namely verb tense and spelling.

On the use of word choice or diction, most students have difficulty in deciding the extent to which the words the writers use are thought suitable and effective for different kinds of writing. This is in line with Richards and Schmidt (2002) which is also influenced by the negative transfer of their first language.

The stabilized errors are also due to another aspect namely reference with $\mathrm{L} 1$ and L2 as seen in the following table.

Table 3: Error with reference to L1 \& L2

\begin{tabular}{|l|l|l|}
\hline No. & \multicolumn{1}{|c|}{ L1 } & \multicolumn{1}{c|}{ L2 } \\
\hline 1. & Hanya itukah? & Is it only? \\
\hline 2. & Tapi perlu diketahui... & But important to know.... \\
\hline 3. & Kita dapat mudah mengetahuinya. & We can easy know it. \\
\hline 4. & Tidak akan cemas & Will not nervous \\
\hline 5. & Karena kurang latihan & Because of lack practice \\
\hline 6. & Merasa kebingungan & Feel confuse \\
\hline 7. & Naskah drama & Text drama \\
\hline
\end{tabular}




\begin{tabular}{|l|l|l|}
\hline 8. & Berbeda dengan & Different with \\
\hline 9. & $\begin{array}{l}\text { Diperiksa sebelum kemudian kita } \\
\text { kumpulkan }\end{array}$ & Check before then we submit it \\
\hline 10. & Kita akan lebih memahami & We'll more understand \\
\hline 11. & Tapi tanpa gramatika & But no grammar \\
\hline 12. & Dapat digambarkan & Can image by \\
\hline 13. & Tugas mengarang & Command writing \\
\hline 14. & $\begin{array}{l}\text { Sama halnya dengan yang memilih } \\
\text { menyimak }\end{array}$ & The same with listening elector \\
\hline 15. & $\begin{array}{l}\text { Jika berhasil untukku, untukmu } \\
\text { mengapa tidak? }\end{array}$ & If it can be effect for me, why not with you? \\
\hline 16. & Lebih meyakinkan pembaca & More persuade the readers \\
\hline
\end{tabular}

The influence of first language word order occurs in the sentence such as:

- Kita dapat mudah mengetahuinya: We can easy know it (We can know it easily)

- Lebih meyakinkan pembaca: More persuade the readers (Persuade the readers more)

The influence also occurs in terms of word-by-word translation such as:

- Naskah drama: text drama (drama text)

- Tugas mengarang: command writing (writing assignment)
Looking at the data, most students seem to experience the negative transfer by translating literally or citing the term used by Johnson (2001), "working through" Indonesian.

It is also obvious that a different way of writing may result in a different number of errors. Timed writing causes more errors for 11 students (65\%), meanwhile 6 students $(35 \%)$ show that they wrote more carefully without using the computer's spelling and grammar check. However, the average of the errors made in both writing tasks is not significantly different as shown by the computation result in table 4 below:

Table 4. Paired Samples Statistics and Difference

Paired Samples Statistics

\begin{tabular}{|c|c|c|c|c|c|c|c|c|c|c|}
\hline & & & \multicolumn{2}{|l|}{ Mean } & \multicolumn{2}{|l|}{$\mathrm{N}$} & Std. Deviation & \multicolumn{2}{|c|}{$\begin{array}{l}\text { Std. } \\
\text { Mean }\end{array}$} & Error \\
\hline \multirow{2}{*}{\multicolumn{3}{|c|}{$\begin{array}{l}\text { Errors in timed writing } \\
\text { Errors in nontimed } \\
\text { writing }\end{array}$}} & \multirow{2}{*}{\multicolumn{2}{|c|}{$\begin{array}{l}9.5294 \\
13.5882\end{array}$}} & \multirow{2}{*}{$\begin{array}{l}17 \\
17\end{array}$} & \multirow{2}{*}{\multicolumn{2}{|c|}{$\begin{array}{l}6.02202 \\
10.21065\end{array}$}} & \multirow{2}{*}{\multicolumn{2}{|c|}{$\begin{array}{l}1.46055 \\
2.47645\end{array}$}} & \\
\hline & & & & & & 10.2 & & & & \\
\hline & \multicolumn{7}{|c|}{ Paired Differences } & \multirow{3}{*}{\multicolumn{3}{|c|}{$\begin{array}{l}\text { Sig. } \\
(2- \\
\text { tailed })\end{array}$}} \\
\hline & \multirow[b]{2}{*}{ Mean } & \multirow{2}{*}{\multicolumn{2}{|c|}{$\begin{array}{l}\text { Std. } \\
\text { Deviatio } \\
\mathrm{n}\end{array}$}} & \multirow{2}{*}{\multicolumn{2}{|c|}{$\begin{array}{l}\text { Std. Error } \\
\text { Mean }\end{array}$}} & \multicolumn{2}{|c|}{$\begin{array}{l}95 \% \text { Confidence } \\
\text { Interval of the } \\
\text { Difference }\end{array}$} & & & \\
\hline & & & & & & Lower & Upper & & & \\
\hline $\begin{array}{ll}\text { Pai } & \text { Errors in } \\
\text { r } 1 & \text { TW- Errors } \\
& \text { in NTW }\end{array}$ & 4.05882 & & 5028 & 2.54 & 730 & 9.45887 & 1.34122 & -1.593 & 16 & .131 \\
\hline
\end{tabular}

From the result, it can be concluded that there is only slight difference between the average stabilized errors in timed writing and non-timed writing. Based on the $t$ distribution table, the value for df 16 at $p<.05$ is 1.729 which means that $t_{\text {obtain }}(1.593)$ is lower than $t_{\text {critical }}$ (1.729). In other words, both writing tasks results in a not significantly different number of errors. The range between both types of writing task (4.06) may occur due to sampling error. Therefore, in assessing writing, both types of tasks are recommended 
to use for their result is not significantly different.

Based on the above analysis, it is noticeable that learners' errors tend to be dynamic. At a particular point of learning course, they may get stabilized temporarily; but they are not fossilized since it happens in a natural learning process. This finding is in line with Fauziati (2010) who found that through some treatments, the stabilized errors can be destabilized as they do not belong to permanent condition.

It can be seen that the finding is in line with relevant studies in which verb tenses are the major source of stabilized or fossilized errors. Georgian students of English also had the same difficulties especially when facing various contexts which become more complicated. This means that they require more efforts andbetter strategies while learning particularly in writing (Nozadze, 2012).

The need to treat the errors by teacher's providing comparison between the forms causing skill interference is a significant alternative as pointed by Nozadze (2012). Had the comparison attitude been really effective, there would have been no problems with error fossilization and minimizing error stabilization.

In general, the types of error found in this study is to some extent similar to those occurring in the writing of Korean college learner. The results of Jung's study (2013) indicated that form-based errors were generally reported much more than meaningbased errors. In addition, learners frequently made errors with the article and grammar categories. Her study suggests that students will develop the

quality as well as the accuracy of their writing when they recognize the most frequent error categories in their L2 writing.

\section{Factors Influencing Errors and Their Types}

Having a look on the students' stabilized errors above, most teachers often generalize that students who are poor in writing are mostly affected by inadequacy vocabularies and limited structure. However, there some other factors which may influence the learners' errors (Richard, 1974; Brown, 2000). Among them are as the following:
1. Language transfer. Sentences in the target language may exhibit interference from the mother tongue. Interference tends to be from the deviant sentence back to the mother tongue.

2. Intralingual interference. It refers to items produced by the learners which reflect not the structure of their mother tongue, but the generalization based on the partial exposure to the target language.

3. Sociolinguistic situation. Different settings for language use result in different degrees and type of language learning. Included here are thus the effects of the learner's particular motivations for learning the second language as well as the effect of the socio-cultural setting.

4. Modality. The learner's language may vary according to the modality of exposure to the target language and the modality of production.

5. Age. Some aspects of the child's learning capacities change as he grows older and these may effects language learning. The child's memory span increases with the age. He acquires a greater number of abstract concepts, and he uses these to interpret his experience.

6. Successions of approximative system. The system are usually unstable in given individuals, since there is invariably continuing improvement in learning the target language.

7. Universal hierarchy of difficulty. It is concerned with the inherent difficulty for man of certain phonological, syntactic or semantic items and structure. Some forms may be inherently difficult to learn no matter what the background of the learners.

Based on the data analysis on above, language transfer, intralingual interference, and sociolinguistic situation are more dominant factors influencing the learners' errors than the other.

The factors above influence the occurence of the stabilized errors which according to Richard (1974) and Brown (2000) involve the following types: 
1. Over-generalization where learner creates a deviant structure on the basis of his experience of other structures in the target language. It can be done by identifying omission, addition, substitution, and ordering.

2. Ignorance of rule restrictions. The failure to observe the restriction of existing structure, that is, the application to context where they do not apply.

3. Incomplete application of rules. The occurrence of the structure whose deviancy represents the degree of development of the rules required to produce acceptable sentences.

4. False concept hypothesized. Faulty comprehension of distinctions in the target language. These are sometimes due to poor gradation of teaching items.

Practically, all causes supporting stabilized error deal with lack of knowledge which becomes the most typical reason. As found by Nozadze (2012) this emphasis on knowledge instead of skills does not totally correspond to contemporary view on language teaching, this is why practice and attention (or content-focused grammar activities) should be stressed more. Morecommunicative practice should be offered, not just formfocused drills.

Further as noted by Nozadze (2012), other reasons are relevant to student's lack of attention, knowledge and practice which seem to be the main causes of error fossilization or stabilization which means teachers need to provide more practice, while students need to be more attentive (probably, more emphasis should be on self-correction).

Similar finding is also given by Hongwu and Jing (2014) investigating the interlanguage fossilization in Chinese college students' written output. Within the same context of EFL (English as a foreign language) learners' writing, there is a tendency towards fossilization. Analysis shows that negative/corrective feedback has played a key role in reducing fossilization of some errors, but it does not work in every case. Their study shows that some errors tend to be fossilized for several reasons. First, language items that do not have a direct form-function relationship are likely to be fossilized. Second,advanced learners create their own language system and neglect the basic rules of grammar. Third, task difficulty takes learners' attention away from form to meaning. Fourth, ingrained thinking patterns have a great impact on how learners organize their thoughts inwriting. It is true that many Chinese EFL advanced learners reach a plateau in the process of acquiring English. However, attention, consciousness, and training of self-monitoring ability will help destabilize their interlanguage system.

\section{How Learners View Their Errors}

Research shows that EFL students were able to successfully self-correct $81 \%$ of the errors they attempted to correct (Applied Linguistics, 2006). This study tries to explore not on how learners self-correct their writing errors but on how they view their own errors in line with Krashen's Monitor Hypothesis. The hypothesis suggests that language items (specifically grammar items) required deliberate thinking before they will manifest themselves in language production. Soon when learners know that correct grammatical form is essential to the success of their writing, they check the sentences before sharing them.

Corder suggested three categories of error namely pre-systematic, systematic and post-systematic errors (in McDonough, 1981). The first category is made by learners trying to understand a new topic, the middle is produced when learners formed a hypothesis which is wrong, while the last is occurred when a point is understood but the learner forgot it. In this study, the stabilized errors made by the learners occur as post-systematic errors.

Based on the review of the questionnaires, $71 \%$ of the students stated that they concern more on the idea development or the essay content rather than the language used. This is due to the emphasis on the ability to monitor one's own correct flaw in the logic of their writing. Meanwhile, $59 \%$ stated that they are not aware of the existing errors although they have used the computer's language tool. Only 24\% could identify their own grammatical errors. Interestingly, $18 \%$ thought that their writing is good enough. 
The way the learners view their error belongs to the basic part of self-regulatory judgement. This also becomes the milestone before they reach further competence or higher skill in expressing their ideas in the form of argumentative writing. As another target, they can develop their critical thinking skill which is defined as the process of purposeful, self-regulatory judgment, which drives problem-solving and decision-making (American Psychological Association, 1990). Concerning this, critical thinking is characterized by one's competencies on using reasoning and logic focusing on what to believe or do based on the mechanism such as conducting conceptual and argument analysis for problem solving and decision making especially inviewing their own stabilized errors in their writing.

In the feedback session, learners knowing their stabilized errors were given opportunity to comment and give input their peer's writing. In this case, they practiced their critical thinking skills which include interpretation (the ability to decide what to believe based on logic and the consequence of the decision), explanation (the ability to communicate the reasoning process to others), and self-regulation (the ability to monitor one's correct flaw in logic). This disposition toward critical thinking can be understood in terms of open-mindedness, inquisitiveness, cognitive maturity, truthseeking, analyticity, systematicity, and critical thinking self-confidence (Ernst \& Monroe, 2004). These have become the beginning stage before they have actually find the solution for eliminating their stabilized error which might occur in their foloowing argumentative writing assignments.

The reasons underlying the occurence of stabilized errors are various. Analysts have proposed six reasons of error, arising from inaccurate learning, inaccurate teaching, wrong guessing, poor memory, the influence of the mother tongue, and the process of learning (Elliot \& Lado, 2007). In Krashen's term the errors made by the learners show their variation in Monitor use (1982, p. 18). Being Monitor under-user, learners do not pay sufficient attention on the language use. Of course it does not mean that over user is better since writing fluency is a matter especially in timed writing. Becoming an optimal user in writing is the best solution to fade away the stabilized error.

Realizing that the error becomes a significant concern of both teacher and students, the way to treat the error is also a prominent issue to discuss. Urgent intervention seems necessary in order to assist students to attain their academic goals, so that there will be minimizing the occurrence of stabilized errors. The basic inquiry is related to Ferris's (2004) pressing question, "... what do we do in the meantime?". Teachers should encourage students to know how and when to use the conventions of the target language, while still acknowledging the value of their own variety. This is also in line with the finding of WardCox (2012) that follows the principles of bidialectism which should underpin the ideal of local and international intelligibility. This fact may empower users of English to use the communicative resources in order to foster a climate of intranational and international communication based on mutual acceptance and respect. Further Ward-Cox (2012) recommends that students be given exposure to extend their linguistic repertoire and consequently their ability to choose the appropriate variety.

\section{CONCLUSIONS}

Writing, especially on argumentation, is essential for academic purpose. Writing learners, therefore, need to develop their writing skills through process approach in which learners are given chance to make progress and to become optimal Monitor users, citing Krashen's term. By becoming optimal Monitor users, students are expected to destabilize their own grammatical errors which may affect the quality of their argumentative writing.

The stabilized errors found in this study cover fifteen types, the dominant of which are verb tense, word choice and spelling. On language form, the stabilized errors mostly occur are omission and addition. Some students also show stabilized errors with reference to the negative transfer of their first language. In this case, language transfer, intralingual interference, and sociolinguistic situation play a role in continuation of such errors to be stabilized. 
In addition, the type of writing task results in different number of stabilized errors. Despite the favor on non-timed writing, some students show more careful language use without using the computer's spelling and grammar check. However, the type of writing task does not affect the number of errors as there is no significant difference between the two writing tasks. It supports the fact that post systematic errors are caused by the variation in student's
Monitor use employed in any type of writing tasks.

Viewing the students' errors occurred naturally in the writing classroom comprised micro and macro linguistics domains. Therefore teachers need to deepen their understanding of the nature of language learning, the learning modalities and strategies which will help the students to minimize stabilized language learning errors.

\section{REFERENCES}

American Psychological Association .(1990). Critical Thinking: a Statement of Expert Consensus for Purposes of Educational Assessment and Instruction (ERIC Document No. ED315423).

Anderson, L. \& Trudgill, P. (1990). Bad Language. Oxford: Basil Blackwell, Ltd., pp 109-118.

Applied Linguitics \& TESOL. (2006). http://appling.wordpress.com/ retrieved December 5th, 2013.

Brown, H.D. (2000). Principle of Language Learning and teaching. New York. Addition Wesley Longman, Inc

Brown, H. D. (2001). Teaching by Principles: An Interactive Approach to LanguagePedagogy. New York: Longman.

Brown, H.D. (2007). Prinsip Pembelajaran dan Pengajaran Bahasa (ed.5). Translated by Cholis \& Pareanom. Jakarta: US Embassy, p.297.

Cook, Guy. 2003. Applied Linguistics. New York: Oxford University Press, p. 6.

Crasswell, G. (2005). Writing for Academic Success: A Postgraduate Guide. London: SAGEPublication Ltd.

Elliot, C. and Lado, R. (2007). Error Analysis of Second Language Learners. http://www.lotsofessays.com/ retrieved December 5th, 2013.

Ernst, J.A. \& Monroe, M. (2004). The Effects of Environment-Based Education on Students' Critical Thinking Skills and Disposition toward Critical Thinking. Environmental Education Research, 10: 4, 507-522.

Fauziati, E. (2010). Dynamicity of Interlanguage Errors: a Case Study of Indonesian Students Leraning English as a Foreign Language. Teflin 57th: Revitalizing Professionalism in ELT as a Response to the Globalized World. Bandung: Indonesia University of Education

Ferris, D. (2004). The "grammar correction" debate in L2 writing: Where are we and where do we go from here? Journal of Second Language Writing, 13:49-62.

Green and Hecht in http://appling.wordpress.com/ retrieved December 5th, 2013. 
Hatch, E., \& Brown, C. (1995). Vocabulary, Semantics, and Language Education. USA: Cambridge University Press.

Hong-wu, Z. \& Jing, X. (2014). Interlanguage Fossilization in Chinese EFL Writing -An Empirical Research of 20 English Major Students. Sino-US English Teaching 11: 4, 248-258.

Jung, M. (2013). Types of errors in college students' L2 writing in EFL environments. Journal of PanPacific Association of Applied Linguistics, 17(2), 123-140.

Knott, D. (2009). Critical Reading vs. Critical Writing, (http://writing.utoronto.ca), retrieved June $29,2013$.

Krashen, S., Dulay, H. \& Burt, M. (1982). Language Two.New York: Oxford University, Press.

Krashen, S.D. (1982). Principles and Practice in Second Language Acquisition. New York: PrenticeHall International, pp.18-20.

McDonough , S.H., (1981). Psychology of Foreign Language Teaching, London: George Allen \& Unwin Ltd.

Mundhenk R.T \& Siebenschuh, W.R. (1978). Contact: A Guide to Writing Skills. Boston: Houghton Mifflin Company,pp. 203-223.

Mason, T. (2002). Critique of Krashen II: The Natural Order Hypothesis. http://www.timothyjpmason.com/WebPages/LangTeach/ retrieved December 5th, 2010.

Nozadze, A. (2012). Dealing with Fossilized Errors while Teaching Grammar. Journal of Education, 1(1):41-46

Oshima A. \& Hogue, A. (1999). Writing Academic English (3rd ed.) New York: Addison Wesley Longman, pp: 260-261.

Richard, J.C. (Eds). (1974). Error Analysis:Perspective on Second Language Acquisition. London. Longman Group Limited

Richard, J.C., \& Schmidt, R. (2002). Longman Dictionary of Language Teaching and Applied Linguistics. London: Pearson Education Limited.

Szasz, T. (1920 - ) Hungarian-born U.S. psychiatrist. Cited in Microsoft ${ }^{\circledR}$ Encarta ${ }^{\circledR}$ 2009. (C) 19932008 Microsoft Corporation.

Ward-Cox M. W. (2012). A Critica Review of Language Errors in the Writing of Distance Education Students. Unpublished thesis submitted to University of South Africa.

White, R. V. (1995). New Ways in Teaching Writing. Bloomington Illinois: Pantagraph Printing. 